\title{
THE CRIMINOLOGICAL HERITAGE OF THE FACULTY OF LAW, UNIVERSITY OF NIŠ
}

\author{
UDC 343.9:378.096(497.11 Nǐs)
}

\section{Filip Mirić}

\author{
Faculty of Law, University of Niš
}

\begin{abstract}
Crime has always attracted the public attention. Criminology, as a science on the forms and causes of crime, has been studied at the Faculty of Law, University of Niš, since its establishment in 1960. In the past 56 years, the Law Faculty in Nis has published numerous publications (textbooks and monograps) on criminology. The aim of this paper is to provide a a brief overview of the most important criminological literature published by the Faculty of Law, University of Niš, which contributed to casting more light on the multifaceted criminological issues. The author also recognizes and commends the dedicated work of Law Faculty teaching staff and the exerted efforts to present these complex issues in a comprehensible way, adapted to the needs of junior and senior law students and the needs of the wider academic, professional and social communities.
\end{abstract}

Key words: Criminology, Faculty of Law, University of Niš.

\section{INTRODUCTION}

Criminology has been studied at the Faculty of Law of the University of Niš since its foundation in 1960. It was initially part of the academic course Criminology with Penology. Under the Law Faculty Curriculum of 1995, the course was divided into Criminology and Penology, which have been studied as separate courses ever since. In the past 56 years, the Law Faculty in Nis has published numerous publications (textbooks and monograps) on criminology. The aim of this paper is to provide a brief overview of the most sigificant criminological literature published by the Law Faculty, University of Niš, which contributed to casting more light on the multifaceted criminological issues. The author also recognizes and commends the Law Faculty teaching staff for their dedicated work and exereted efforts to present these complex issues in a comprehensible way, specifically adapted to the needs of law students at all levels of study as well as the

Received November 22 $2^{\text {th }}, 2017$ / Accepted August $7^{\text {th }}, 2018$

Corresponding author: Filip Mirić, LL.D., Associate for Postgraduate Studies, University of Niš, Faculty of Law, Trg kralja Aleksandra 11, 18000 Niš, Republic of Serbia

E-mail: filip@prafak.ni.ac.rs 
needs of the wider academic, professional and social communities. The paper will show how the most important criminological issues were analyzed in the textbooks and monographs published by the Faculty of Law, University of Niš. As all Criminology textbooks published since 1960 are not available, the presented sample of textbook literature is illustrative. Nonetheless, this overview provides an insight into the development of teaching and scientific activity at the Law Faculty in Niš, as well as the development of criminology as a science in the Serbian context. The dedicated work of professors and assistants has certainly served as an incentive for generations of young lawyers and criminologists who acquired their first knowledge in this criminal law area at the Faculty of Law, University of Niš.

\section{ANALYSIS OF THE MOST IMPORTANT CRIMINOLOGICAL TEXTBOOKS PUBLISHED AT THE FACULTY OF LAW, UNIVERSITY OF NIŠ}

In this part of the paper, the author analyzes the most important criminological literature published at the Faculty of Law, University in Niš, from 1960 to 2012. Such a long period covered by research provides the opportunity to explore the complete opus of Criminology professors at the Faculty of Law in Niš. A vast majority of textbooks on Criminology was published by the Publication Centre of the Faculty of Law, University of Niš, as the official publishing unit envisaged in the organisational structure of the Law Faculty in Niš.

In analyzing the criminology textbook published by the Faculty of Law, University of Niš, we should definitely start from the textbook Criminology, written by prof. Milan Milutinović and published in 6 editions (1969, 1972, 1979, 1981, 1984 and 1990). In this textbook, all questions of importance for the development of criminology, as well as penology, criminal policy and victimology as "branches" of criminology, are presented in a systematic way (Milutinović, 1990: 19). One of the prominent features of this textbook is the extensive analysis of criminogenic factors of both endogenous and exogenous type that are explained in detail but in a clear and understandable way. It is a special quality of every useful textbook to be comprehensible to students. Regardless of the fact that more than two and a half decades have passed since the publication of the last edition of this textbook, it is an inevitable reading material for students at all levels of study, in the process of adopting and deepening criminological knowledge.

The textbook Criminology by prof. Slobodanka Konstantinović Vilić and Vesna Nikolić Ristanović, published in 2003, was preceded by the book The Foundations of Criminology published in 1992. Unlike The Foundations of Criminology, where the authors clearly systematized the basic knowledge in the field of criminology, Criminology contains a complex and detailed synthesis of knowledge about crime, which was the result of extensive research into the older and newer world criminological literature and the authors' own research into certain forms of crime. Thus, the Criminology textbook synthesized the latest knowledge about the concept and subject matter of criminology. In addition, the authors provided a complex analysis of phenomenological and etiological characteristics of crime, paying special attention to methodology and victimology, as well as to new forms of crime and specificities of crime with regard to perpetrator and victim (Konstantinović-Vilić, Nikolić-Ristanović, 2003:13). This textbook is primarily intended for students of law faculties and other related faculties in the field of social sciences and humanities, but it may also be 
useful for practitioners who encounter criminological issues, problems and challenges in their practical work (Konstantinović-Vilić, Nikolić-Ristanović, Kostić, 2009: 15-16).

Due to the rapid development of criminology as a science, there was a need to update the criminology textbooks from 1992 and 2003 by introducing new scientific knowledge and the results of the conducted criminological research. Thus, a new edition of the Criminology textbook was published in 2009. In comparison with the previous two textbooks, this new 2009 edition contains changes in the chapter on the phenomenological characteristics of crime and in other parts of the textbook. Criminological typology includes the consideration of several new forms of crime, such as: hate crimes, violence in sports, crime of persecution, mobbing, political crime, terrorism, trafficking in human beings, and crimes comitted by women? In addition, the etiological part is supplemented by new theoretical explanations of crime (the theory of neutralization; peacemaking criminology and restorative justice; globalization theories) and the analysis of the impact of globalization and transition on crime. Wherever possible and meaningful, the authors updated the statistical and research data, and provided a new index of terms and concepts. A particularly important novelty is the development of summaries, questions and discussion topics, topics for seminar papers, key words and useful internet addresses at the end of individual units, which should facilitate students' learning and encourage further criminological research.

A tendency to provide contemporary criminological knowledge to the students of the Faculty of Law in Niš was further reflected in the publication of a new edition of the Criminology textbook, which was written by Slobodanka Konstantinović-Vilić, Vesna Nikolić-Ristanović and Miomira Kostić, and published in 2012. As compared to the previous publication, the new textbook includes updates in the phenomenological part, particularly regarding the scope, dynamics, structure and new forms of crime in Serbia and worldwide. Considering the significant changes in the criminal law and criminal procedural legislation of the Republic of Serbia which were introduced after the publication of the previous (2009) textbook, it was also necessary to update the statistical data, to include new research results and make a new index of terms and concepts (Konstantinović-Vilić, Nikolić-Ristanović, Kostić, 2012: 15). These changes have facilitated the acquisition of scientific and academic knowledge provided in the textbook. Due to the abundance of practical examples, all these textbooks can be highly beneficial to students of undergraduate, master and doctoral studies, as well as to holders of judicial functions, employees of internal affairs bodies, and all others who need to study criminology and apply criminological knowledge in practice.

Criminology is a multidisciplinary science and, in order to provide a comprehensive analysis of crime, it is very important to use knowledge from other sciences, such as medicine, psychology, psychiatry, etc. Some important criminological questions were also analyzed in textbooks from other areas of criminal law, among which forensic psychiatry has a special place. Thus, in the textbook Forensic Psychiatry, prof. Zoran Ćirić analyzes the important issues related to the psychological mindset of different types of perpetrators, as well as the endogenous factors of crime. This textbook is primarily intended for the education of future legal professionals at undergraduate and postgraduate studies (of both second and third degree), but it also contains very important elements that may be highly relevant in the education of medical students and psychiatric specialists (Ćirić, 2013). Some older literature also illustrates the relevance of acquiring the basic knowledge in the field of psychiatry and psychology for law students, future legal practitioners and the judiciary, particularly in terms of the psychology of court proceedings. The textbook Introduction to Psychology of Court Proceedings (1980), authored by prof. Mihajlo Aćimović, is an excellent example of such 
literature. This book analyzes the psychological status of individual participants in criminal proceedings (defendants, public prosecutors, witnesses, expert witnesses, etc.). Special attention is given to the psychology of adjudication, as one of the most important stages in the criminal procedure. Psychological processes pertaining to all participants in court proceedings are of great importance in the judicial process of evaluating their testimonies. Therefore, the knowledge of psychology of court proceedings is necessary for achieving the criminal procedure goals (Aćimović, 1980). This body of knowledge is also very useful for criminologists when analyzing the efficiency of criminal procedure in combating crime. Therefore, textbooks of this kind have a significant role in criminological literature.

The book Crime Prevention Policy, written by prof. Dragan Jovašević and prof. Miomira Kostić is an important study on criminal policy. Although it is primarily intended for students (of all academic levels) who study crime prevention policy at different faculties, the book may be highly useful in the professional work of a wider range of practitioners engaged in combating various forms of crime. This book is also significant for the study of victimology because it deals with some issues of importance for preventing the victimization of certain categories of people, such as homeless people and the elderly. Apart from being important for students of undergraduate, graduate, specialist and post-graduate law studies, the book may be useful to students of criminalistics, security and special education faculties, as well as to other persons who are in the process of education or professional development and to those who are involved in preventing and combating crime in their everyday professional work (Jovašević, Kostić, 2012: 12). From the aspect of criminal law literature, the distinctive feature of this book is the provided analysis of the historical development of criminal policy. The authors analyzed the theoretical concepts of different criminal law schools and learnings (including the classical and anthropological school, the school of social defense, and the contemporary tendencies in the policy of suppressing crime), and examined the nature and causes of various forms of criminal behavior. The comprehensive coverage of crime prevention policy is of great criminological significance. In some way, crime prevention policy sublimates the knowledge of a number of sciences and scientific disciplines that deal with the study of crime as a negative social phenomenon, its manifestations, causes and prevention. In this regard, the introduction of a special course on Crime Prevention Policy into the curricula of the undergraduate, master and doctoral studies at the Law Faculty in Niš would significantly contribute to broadening the students' knowledge on this subject matter. This should be taken into account during the subsequent reform of study programs at the Faculty of Law, University of Niš.

The monograph Victimology - the basic tenets through individual topics (2012), written by prof. Slobodanka Konstantinović-Vilić and prof. Miomira Kostić, was created from the need to provide the students of the Law Faculty in Niš with adequate literature for the course in Victimology at the undergraduate academic law studies. The authors carefully selected the topics to explain the causes and consequences of particular forms of victimization: victims of street crime, victims of domestic violence and human trafficking, poverty and social exclusion as one of the most significant factors of social exclusion, violence in sports, etc. This monograph is very important for criminology, bearing in mind that "victimology is seen as a subdiscipline of criminology" (Kostić, 2012: 3). In particular, the authors provided the analysis of different theoretical postulates and schools of thought in victimology. The special quality of this monograph is a rich glossary of basic concepts used in victimology, which greatly facilitates the readers' understanding and analysis of the content. This monograph is a very important step towards creating a textbook in the field of victimology. 
The monograph Murders in Southeastern Serbia (2014), authored by Assistant Professor Darko Dimovski has significantly contributed to the criminological investigation of murders as the most severe form of crime. This topic was part of the author's doctoral dissertation Criminological Explanation of Murder, which he defended at the Faculty of Law, University of Niš in 2013. The criminal offence of murder is a topic that has always attracted public attention, particularly through sensational headlines in the media. In the past, newspaper reports on murders were significantly different from the reports today. In some newspaper articles, the authors sometimes justified or even invoked murder. In many cases, reports were based on "unofficial" sources, talking with the victim's family members or persons from the immediate environment of the perpetrator and the victim; thus, the authors of these reports created their own "truth" about the perpetrator, the victim and the circumstances of the committed criminal act. In this monograph, the subject matter of the author's interest was not the nature of journalists' reports on murders but such approach to journalism was one of the factors that undoubtedly drew the attention of socioligists and criminologists. In order to prevent the fabrication of "the journalist's truth" and its negative impact on the public perception of murder, there were scientific efforts to conduct detailed and fundamental research on the phenomenological and etiological characteristics of murder. Different researchers explored murder patterns, causes, consequences, forms of punishment, and the possibility of resocilizing the murderers. Although all these issues are very important for understanding the concept of murder, a one-way approach (no matter how fundamental and serious) cannot significantly contribute to understanding any phenomenon. The complex phenomenon of murder must be accessed comprehensively from an interdisciplinary perspective. This applies both to understanding the concept of murder in the broadest sense of the word, the process of resolving each individual murder case, and especially the adjudication stage of pronouncing a sentence and imposing the appropriate punishment. Former research did not address this issue, particularly in terms of the immediate environment. It is much easier to analyze the results of research elsewhere, beyond time, space and ethnic understanding of one's own environment; so, it is challenging to explore the investigative procedure of murder in our country (Dimovski, 2014: 1-2). In this monograph, the author presents several proposals for the reform of criminal legislation on murder and homicide that may be very interesting to the legislator during subsequent revisions of the Criminal Code of the Republic of Serbia. The author points out that partial reform of the Criminal Code may need to be considered, with regard to introducing the criminal offence of manslaughter, if the commited crime contains no elements of the aready existing forms of murder and homicides commited by exceeding the necessary defence. In Serbian judicial practice, the case where the husband is murdered in his sleep by the wife who has been physically, psycholocially, sexually abused and exploited for years has been treated as an aggravated form of murder. The question is whether it is justifiable to qualify such a criminal offense as a serious form of murder, which is punishable by a term of imprisonment of up to 40 years if the wife had been mistreated by her husband and subjected to ongoing abuse for many years before the fatal incident. Therefore, it would be reasonable to introduce a special form of privileged murder: the murder commited by a person who has been victim of previous abuse. In order to eliminate the inconsistencies in the application of the covert investigator's institute in detecting the criminal acts of organized criminal groups, it may be useful to envisage the criminal offences of murder committed by an organized group and by a hired hand, and another form of privileged murder: the criminal offence of murdering a person who had 
previously persecuted the perpetrator of this murder. The precondition for introducing the latter form of murder is the definition of the crime of persecution in our criminal legislation (Dimovski, 2014: 255). In conclusion, the monograph Murders in Southeastern Serbia, is a valuable criminological study that can be useful not only to students but also to theoreticians who study this criminological and criminal law phenomenon.

As a result of the endeavour to continuously improve the teaching process at the Faculty of Law in Niš, some monographic publications have been included into the list of additional literature for exams at different levels of study. It may be illistrated by the monograph Juvenile Delinquency through the prism of newspaper reports in Politika 1904-1941, written by Miomira Kostić, Darko Dimovski and Filip Mirić, and published in 2015. This book has several thematic units. The theoretical part of the research includes scientific facts and descriptions on childhood and adolescence as important developmental periods in the life of each human individual. In particular, the authors analyzed specific physical and psychic features in the development of personality of children and youth in different periods of their social development, as well as the characteristics of their social and legal position. In the first part of the monograph, special attention was given to the history of the development of criminal liability of children and young people in Serbia, so that this knowledge would be available and comparable with the methods of reporting on the delinquent behavior of children and juveniles in the period 1904-1941. The authors focused on distinctive criminogenic factors and exogenous characteristics related to the causal relation between content in the mass media and the frequency of juvenile delinquency. On the one hand, juveniles can become participants in criminal events under the impact of the consumed content from the mass media, by imitating or identifying with the criminal conduct; on the other hand, mass media can contribute to shaping the public opinion about juvenile delinquents and other categories of criminal offenders. The second part of the monograph elaborates on the collection, recording and analysis of the content of articles on juvenile delinquency published in the Politika daily in the observed period. The structure covers four time periods (1904-1923; 1924-1930; 1931-1935; and 1936 to 1941) and within each period the offences are grouped according to the subject matter (e.g. property crimes, misdemeanours, felonies, etc.). All collected articles are analyzed and grouped into the specific type of delinquent behavior. The Varia section presents all available contents which were directly or indirectly related to the crime rate in Serbia at that time, especially pertaining to juvenile offenders. It is also important to point out to the recorded contents that describe various forms of deviant behavior of children and minors (such as: gambling, vagrancy, suicide, running away from home and truancy from school, etc.) as well as cases of their victimization, especially in the form of domestic violence and peer violence (Kostić, Dimovski, Mirić, 2015: 3-4). By the decision of the Academic Council of the Faculty of Law, University of Niš (Decision No.01-1776/12 of 24.09.2015) this monograph was entered into the list of additional literature for the elective course Violence crimes at the graduate (master) academic law study programe and the elective course Criminology of Juvenile Delinquency at the doctoral academic law study program, thus attaining the character of a textbook.

The criminological heritage of the Faculty of Law, University of Niš, also includes lexicographic publications. Thus, the Criminal Law Lexicon, written by prof. Dragan Jovašević, contains definitions and explanations on various criminological phenomena. Considering its nature, character and content, the Criminal Law Lexicon has a wide-ranging scope and practical value. It comprehensively presents the criminal law matter (Jovašević, 
2006: 8). This lexicon can be useful to law students and students of other social sciences, as well as to legal professionals in the field of crime investigation, criminology and penology.

Based on this brief overview of the most important criminological literature published at the Faculty of Law, University of Niš, it can be concluded that the teaching staff and associates have exerted great efforts in the past 56 years since the establishment of this higer education insitution to provide students with adequate textbook literature in the field of criminology, which could help them aquire criminological knowledge and prepare for criminology-related exams at all levels of law study. Their pedagogical and scientific work has encouraged the development of scientific research in criminology and many related areas, which certainly have a bright future at the Faculty of Law, University of Niš.

It should be noted that the work of professors, assistants and associates of the Faculty of Law, University in Niš in the field of criminology was recognized and valued at the level of the University of Nis, as an independent higher education institution. Namely, starting from 2015, prof. Miomira Kostić was appointed Editor-in-Chief of the scientific journal Facta Universitatis: Law and Politics Series, which is another confirmation of her commitment to the development of criminology as a science. In addition, the first thematic issue of this journal for 2017 was dedicated to topics from the field of criminal law, criminal procedure, criminology, penology, victimology and criminalistics; the guest editor of this thematic issue was Assistant Professor Darko Dimovski). ${ }^{1}$

\section{CONCLUSION}

A rich criminological opus is the result of the dedicated work of professors, assistants and associates of the Faculty of Law, University of Nis. Although all the textbooks analyzed in this paper are not directly related to criminology, as they deal with other criminal law areas, this brief analysis has shown that valuable literature is available to students as textbooks for preparing their exams and as good theoretical grounds for their research. The development of criminological research at the Faculty of Law, University of Niš, is aligned with the development of criminology as a science in the world. In the first years after the establishment of the Law Faculty in Niš, criminology was studied within the subject called Criminology with Penology. Although this approach did not sufficiently consider the particularities of either Criminology (as a science of phenomenological and etiological characteristics of crime) or Penology (as a separate scientific discipline on different forms of treatment that can be applied to perpetrators of criminal offenses), it was important for the development of both Criminology and Penology as separate but correlated subjects. Namely, without knowing the factors, conditions and causes of crime, an adequate criminal sanction cannot be imposed on the perpetrators of criminal offenses. On the other hand, the theoretical concepts of criminal phenomenology and etiology are best examined in penological practice, reflected in the work of penitentiary institutions. The systematization of criminological textbooks, their short analysis and interpretation of the basic scientific findings contained in them can be beneficial not only to students of law faculties in acquiring basic criminological knowledge but also to researchers and scientists in the process of finding ideas and gathering materials for their own research. Further criminological research and more

\footnotetext{
${ }^{1}$ See more: Facta Universitatis -Law and Politics Series, No.1, 2017.
} 
literature could definitely be of great benefit to the academic and scientific community in the future.

Criminological knowledge must be presented to law students and future legal professionals in a way that will encourage their critical thinking and independent scientific research work. It is not always easy to find the right measure between academic and practical, theoretical and empirical approaches. Today, there are complaints among students that current legal education does not provide relevant practical knowledge and skills, and that there is too much theory in the syllabi of most law subjects. Although these complaints are sometimes justifiable, we cannot ignore a very important fact: it is impossible to become a good law practitioner without acuiring a solid theoretical knowledge. As a matter of fact, it is this unity of theoretical and practical approach that is the most striking feature in criminological research, particularly bearing in mind the multifaceted nature of crime as a socially danderous phenomenon. Many generations of former Law Faculty students, who are current holders of the most important public and judicial functions, law practitioners, scientists and researchers, are extremely grateful to our professors, prof. Slobodanka Konstantinović-Vilić and prof. Miomira Kostić, for teaching us this valuable lesson. Many generations of successful lawyers and criminologists who acquired their first legal knowledge and skills at the Faculty of Law, University of Niš, are the most valuable proof that the commitment of the teaching staff of this higher education institution has not been in vain.

\section{REFERENCES}

Aćimović, M. (1980) Uvod u psihologiju sudskog postupka (Introduction to Forensic Psychology), Beograd: Savremena administracija.

Dimovski, D. (2014) Ubistva u jugoistočnoj Srbiji (Murders in South-East Serbia), Niš: Centar za publikacije Pravnog fakulteta.

Facta Universitatis - Series Law and Politics University of Niš, No.1, 2017.

Jovašević, D. (2006) Leksikon krivičnog prava (Criminal Law Lexion), Belgrade: Službeni glasnik.

Jovašević, D., Kostić, M. (2012) Politika suzbijanja kriminaliteta (Crime Prevention Policy), Niš: Centar za publikacije Pravnog fakulteta.

Konstantinović-Vilić, S., Nikolić-Ristanović, V. (2003) Kriminologija (Criminology), Niš: Centar za publikacije Pravnog fakulteta u Nišu.

Konstantinović-Vilić, S., Nikolić-Ristanović, V., Kostić, M. (2009) Kriminologija, (Criminology), Pelikan print.

Konstantinović-Vilić, S., Nikolić-Ristanović, V., Kostić, M. (2012) Kriminologija (Criminology), Niš: Centar za publikacije Pravnog fakulteta u Nišu.

Kostić, M. (2012) Viktimologija-savremeni naučni pogled na kriminalitet i njegovu žrtvu, in: Konstantinović Vilić, S., Kostić, M. Viktimologija - osnove učenja kroz pojedinačne teme (Victimology- the basic tenets through indivudual topics), Niš: Centar za publikacije Pravnog fakulteta Univerzitet u Nišu.

Kostić, M., Dimovski, D., Mirić, F. (2015) Maloletnička delinkvencija kroz prizmu novinskih izveštaja u dnevnom listu Politika 1904-1941, (Juvenile delinquency through the prism of newspaper reports published in the daily paper Politika 1904-1941), Niš: Centar za publikacije Pravnog fakulteta Univerziteta u Nišu.

Milutinović, M. (1990) Kriminologija (Criminology), Beograd: Savremena administracija.

Ćirić, Z. (2013) Sudska psihijatrija, (Forensic Psychiatry), Niš: Centar za publikacije Pravnog fakulteta Univerziteta u Nišu. 


\section{KRIMINOLOŠKO NASLEĐE PRAVNOG FAKULTETA UNIVERZITETA U NIŠU}

Kriminalitet je oduvek privlačio pažnju javnosti. Zbog toga se, kriminologija kao nauka o pojavnim oblicima i uzrocima kriminaliteta, izučava na Pravnom fakultetu u Nišu od njegovog osnivanja 1960. godine. Tokom 56 godina postojanja Fakulteta mnogobrojna su izdanja posvećena kriminologiji. Reč je o naučnim publikacijama udžbeničkog i monografskog tipa. Cilj rada je da se kroz kratak prikaz najznačajnijih kriminoloških studija u izdanju Pravnog fakulteta Univerziteta $u$ Nišu, još jednom oda zasluženo priznanje nastavnicima i saradnicima na višegodišnjem predanom radu i uloženim naporima da se kompleksna kriminološka građa predstavi na način prilagođen studentima svim nivoima studija, ali i široj akademskoj i društvenoj zajednici.

Ključne reči: kriminologija, Pravni fakultet, Univerzitet u Nišu.

Proofreading and copy-editing:

Gordana Ignjatović 